kW van het maximmm der groep, de laagspanningsverbruikers met $f$ 53.- $\mathrm{kW}$ van het maximum van elke groep.

s'uplus liWh-liosten.

Voorts wordt jedere verbruikersgroep belast met de surpluskWh-kosten, evenledig alu de afgenomen hoeveelheid $\mathrm{kWh}, \mathrm{nl}$. de hoogspanningsverbruikers met $0,05+\mathrm{K}$ et. per $\mathrm{kWh}$, de laagspanningsterbruikers met $0,058 \mathrm{~K}$ et. per $\mathrm{kWh}$.

De resultaten kumnen nu als volgt worden samengevat:

lloogsp.gr.verhi: :

$f 283.000 \ldots+f 33 .-\mathrm{kW}+0.054 \mathrm{~K}$ ct $/ \mathrm{kW} h$.

Idagusp.grr.verbr.:

f $51.900--+53 .-\mathrm{kW}+0.058 \mathrm{k} \cdot \mathrm{ct} / \mathrm{kWh}$.

luagsplkl.verbr.:

f $966.600 .-+f 53 .-/ \mathrm{kW}+0.058 \mathrm{~K}$ ct $/ \mathrm{kWh}$.

Iit het bovenstaande blijkt, welke kosten elke gloep in zijn geheel verool'zakt.

Een verdeeling der kosten over de verbruikers van elke groep afzonderlijk is niet mogelijk, ondat cen bluikbare maatstaf hiervor niet kan worden gevonden.

Sien tarifieering, volledig gebasecrd op de kosten, dic elke afnemer veroorzalit, is practisch onmogelijl.

IIet vaststellen echter van de surplus-kW-kosten voor elken verbruiker afzonderlijk, doch ook slcehts als geniddelde ran zijn groep, is wel mogelijk, indien de z.g. ,diversiteits-factor", van (le maximale belasting voor deze verbruikers bekend is. I) som der maximale belastingen in de spitsuren bleek bij de P.U.F.M. ongeveer $1.6 \times$ de gezamenlijke maximale belasting te zijn, wandoor de op elken verbruiker drukkende surplus$\mathrm{kW}$-kosten ongeveer $\frac{1}{1.6}$ van de gozamenlijke surplus-kW-kosten bedragen.

1)eze zijn dus roor:

afzonderlijke hoogsp.gr.verbruikers:

$$
10 \times f 33 / \mathrm{kW}=f 20.60 / \mathrm{kW}
$$

afzonderlịke laagsp.gr.verbruikers:

$$
\frac{10}{10} \times f 53 / \mathrm{kW}=f 33.10 / \mathrm{kW}
$$

De hier gevonden walrden voor de versehillende onderdeelen der leveringskosten kumnen nu worden gebruikt om na te gaan, in hoeverte bijw. cen tallief roor een nieuwe toepassing een overschot toelat boven de surplus-kosten der levering, welk overschot dan als een bijdlage in het totaal der vaste kosten kan worden beschouwd.

Ten slotte bespreken de schrijvers nog het z.g. vastrechtturief voor woonhuizen, dat in N'ederland algemeen wordt tocgepast. Dit tarief toch is nict allecn aangepast aan de waddeering der verbruikers, doch bovendien aan do samenstelling der leveringskosten.

Het vaste bedrag is de hijdrage in de vaste kosten, de (lage) kWh-prijs is cen vergoeding voor de surplus-kW- en -kWhkosten der levering. De $k$ Wh-prijs stemt tevens overeen met de wardeering der afnemers voor de stroomlevering voor huishoudelijke kracht- en warntedoeleinden en mecrder lichtverbruik.

Bij een gebruiksduur ran 3000 tot 5000 uren van de maximale belasting, zooals voor stroomafname voor huishoudelijike doeleinden bij een groot aantal klein-verbruikers mag worden aangenomen, zouden volgens de boven aangegeven cijfers de kosten per kWh als volgt kumnen worden berekend:
De surplus $\mathrm{kW}$ - vermeerderd met de surplus kWh-kosten zijn $\frac{\mathrm{f} 53 .-}{3000}+0.058 \mathrm{~K}$ ct. resp. $\frac{\mathrm{f} 53 .}{5000}+0.058 \mathrm{~K}$ ct.

Bij een waarde van $K=f 7$.- per ton zullen deze kosten 2.18 ct. resp. 1.47 et bedragen. Deze uitkomst toont niet alleen aan de juistheid van het lage $k W h$-tarief bij vastrecht, doch is tevens cen duidelijke weerlegging van de opratting, wolke dikwijls door coneurrenten der electriciteitslmedrijven wordt gepropagecrel, nl. dat deze bedrijven verlies ljjden op het kWhtarief bij toepassing ran vastrecht.

Wij zijn hiermede genaderd tot het einde der analysecrende beschouwingen van de Iteeren Irs. Könings en Bartels. Yij rormen met de doorwochte studiën van Prof. (ielissen en D)'s. Snel en van Int. Lutofs op hetzelfde terrein een wardevol compendium ter verklaring van de cigenardige versohijuselen, die het kostenprobleem van electrische energie te aanschouwen geeft. Toch erkennen de genoemde schrijvers zelf dit problecm nict tot cen volledige oplossing te hebben gebralcht. Moge thans ook ecns van de zijde der bedrijfseconomen cene poging worden gedaan om door een diepganand onderzoek het werk der electro-technici te completecren. Ilet vaagstuk verdient onze intense belangstclling èn wegens de cnorme kapitalen, die de electriciteitsvoouziening vereiselst in wegens het gewicht eener differentiecle tarievenpolitick, gebaseerd op nauwkeurig geanalyseerde kostprijzen, teneinde een voldoende rendement der geïnvesteerde liapitalen te warborgen.

J. .J. M. II. NI.JST

\section{ADMINISTRATIEVE FABRIEKSORGANISATIE} (Slot)

\section{HET WMAILLEEREN IOER RTWI AR'TIKELEN.}

Het gemalen email wordt naar behoefte met water vermengd; in de emaillecrderij zijjn stecds bakken vloeibare cmail van verschillonde kleur aanwezig. De te emaillceren ruwe artikelen worden stuk voor stuk in de grondkleurstof gredompeld; de artikelen worden daarna in een emailleeroven geplaatst, waarin de grondkleur onder hooge temperatumr wordt ingebrand. Na afgekoeld te zijn, worden ze wederom in kleurstof gedompeld, zoo noodig gemarmerd, gebiesd of geschabloneerd (n daarna mog eens in den emaillecroven geplaatst. Na afkoeling worden de artikelen stuk voor stuk in le pakkerij in papier gepakt en opureslagen in het magazijn rool gereede goederen.

De samenstelling van het vlocibal'r email berust op stancharden. waaran het verbruik van gomalen email cn water getoetst worden.

\section{Oventiosten.}

De kosten van het emailleeren der versebillende artikelen worden per serie bepald. Voor dit onderdeel van het bedrijf is het van belang de ruimte van de met een hooge temperatuur werkende oven zooveel mogelijk te benutten. Derlalve zal mon roor elke soort resp. maat artikel dienen vast te stellen het rantal, dat tegelijk in de oven kan worden geplaatst. Zooals hoven reeds werd aangegeven, is het gewenscht, dat deze maxima overeenkomen met de tegelijkertijd in de zoutzuuroplossing brhandelde stuks.

Ten einde het jendement van de oven te berekenen, dient men de theoretiseh bereikbare ovendag-produetic uit te drukken in het product van de (maximal te gebruiken) oveninhoud en de werktija. De ingenomen mimte en de werktijd 
van elke serie (eveneens uit te drukken in de eenheid kubiekemeter-uren) zijn bekend, zoodat de werkelijke ovendag-productie vastgesteld kan worden door samenvoeging ran de eenheids-ejfers der bewerkte series. De verhouding tusschen het verkregen totaal en het theoretisch bereikbare cijfer geeft aan het rendement van de oven-inhoud, hetwelk, in verband met de hooge ovenkosten, van overwegend belang is.

Wordt van elke seric het, ten opzichte van de oven-inhoud, maximum aantal stuks in de oven geplaatst, dan kan het rende ment op cenvoudiger wijze berekend worden. De te gebruiken inhoud is dan bij alle factoren gelijk, zoodat de verhouding wordt bepaald door de werktijd van de oven en het totaal der standaard-tijden van de bewerkte series. Anderzijds worden op grond van het verschil van de twee laatstgenoemde factoren berekend de efficiency-verschillen van de emailleeroven.

\section{Fabrieksadministratie.}

Het emailleeren der artikelen wordt ,gepland" op de wijze, zooals wij zulks bij de ruw-fabricage-afdeeling hebben besproken. Behalve met de reeds aangegeven factoren moet de Planning rekening houden met de capaciteit van de oven, wal'op wij boven de aandacht gevestigd hebben. De fabrieksadministratie wordt gevormd door productie-orders, welke zich ten opzichte van het ontstaan, de behandeling, het verloop en de contröle in hoofdzaak overeenkomstig de orders van de ruwfabricage-afdeeling ontwikkelen.

Ten aanzien ran de toerekening der ovenkosten merken wịj nog op, dat het inbranden van de grondkleur en het inbranden van de bovenkleur als twee afzonderlijke bewerkingen worden beschouwd, in verband warmede zich an de productic-orders o.m. 2 strookjes bevinden, warop de desbetreffende standaardtijden, de werkelijke tijden en de verschil-tijden afzonderlijk worden vermeld.

opslag van eindproducten.

De opslag van de gereede goederen in het magazijn blijkt uit de, door den magazijnmeester ingezonden, afleveringskaart, welke wordt vergeleken met de laatste strook, ontvangen van de pakkerij, warrop het aantal in papier gewikkelde artikelen is aangeteekend.

De magazijnmeester administreert de voorraden op kaarten per artikel, terwijl ten kantore een analoge administratie wordt gevoerd, waarlij, wat betreft de ingang, eveneens uitsluitend hoeveelheden worden aangeteckend. Het verband met ile Hoofdadministratie wordt gecontrôleerd door confrontatic van de tegen de standaard-prijzen omgerekende voorraad-saldi met het saldo der grootboekrekening Gereed-product.

De kosten van de volgens de gecombineerde kostprijskaarten geproduceerde en gereed gekomen artikelen worden berekend op basis van de standaard-kostprij.js. De aldus berekende totalen en de op de kostprijskaarten aangeteekende verschillen worden overgenomen in een Productie-register, welke de aansluiting vormt tusschen de Kostprijsadministratie en de Hoofdadministratie. De uit het register getrokken journaalpost luidt als volgt:

Gereed product in magazijn

Efficiency-verschillen emailleeroven (D) of C) Uitval serie A

AAN Verbruikte r'uwe artikelen

AAN Berekende magazijnkosten

A.AN Berekende stukloonen emailleerderij

AAN Berekende indirecte productiekosten emailleerderij

AAN Berekende kosten emailleeroven

AAN Berekende stukloonen pakkerii

AAN Berekende indirecte productiekosten pakkerij

AAN Berekende uitvalkosten serie $\mathrm{A}$.

\section{Uitval.}

De verliezen wegens afgekeurde artikelen vragen ten volle de aandacht van den calculator, daar cen nauwkeurige berekening den bedrijfsleider het belang van de mislukkingen doet kennen, zoodat deze door gedurige waarneming van het productie-proces de oorzaken zal trachten op te sporen.

Indien tengevolge van een bewerking of door andere oorzaken uitval zal optreden, dan dient op statistische wijze het normale aantal afgekcurde artikelen vastgesteld te worden. De kosten van de normale uitval worden gevormd door de materiaal- en directe loonkosten tot aan de bewerking, waarbij de mislukking werd geconstateerd (niet de bewerking, die als oorzaak kon worden aangewezen). De berekende uitvalkosten (te verminderen met een eventucele opbrengst) vormen een deel van de kostprijs, zoodat zij door middel van ecn opslag ingecalculeerd worden. Mocht door de aard van het artikel de mislukkingskans voor de verschillende artikelen verschillend zijn, dan zal voor elke serie een normale uitval resp. een opslagpercentage bepaald moeten worden.

Tegenover de in het product berekende uitvalkosten dienen de werkelijke kosten uit dien hoofde gesteld te worden. De loonstrooken geven aan, bij welke bewerkingen de effectieve uitval geconstateerd werd, zoodat op grond daalvan de werkelijke uitvalkosten berekend kumnen worden. Bij volgens de productie-begrooting geprojecteerd verloop zullen de rekening elkaar dekken; bij afwijkend verloop ontstaat een debetof credit-saldo.

De statistische waarneming van de uitval geschiedt door middel van een register, waarin de aantallen volgens de statistiekkaartjes van gelijksoortige series worden aangeteekend. Thet register geeft een overzicht van het verloop der aantallen bij alle bewerkingen, zoodat de afwijkingen onmiddellịk opvallen.

\section{Stukloonadministratie.}

Bij dit onderdeel van het bedrijf zullen wij de stukloonadministratie aan een ver(lere bespreking onderwerpen. $\mathrm{Na}$ aanteekening van het aantal stuks en de begin- en eindtijden zijn de bovenaangegeven loonstrooken (model 5) geparafeerd

Model 5.

\begin{tabular}{|c|c|c|c|c|c|c|c|c|c|}
\hline \multirow{2}{*}{$\begin{array}{l}\text { AFD. } \\
\text { Nr.2 } \\
\text { PERS } \\
\text { Nr. }\end{array}$} & $\begin{array}{l}\text { ORDER } \\
\mathrm{Nr} \text {. }\end{array}$ & \multirow{2}{*}{$\begin{array}{l}\text { ART. } \\
\text { Nr. } \\
\text { SERIE } \\
\text { Nr. }\end{array}$} & $\begin{array}{l}\text { LoON } \\
\text { p. } 100\end{array}$ & $\begin{array}{l}\text { WER KM. } \\
\text { Nr. }\end{array}$ & & $\begin{array}{l}\operatorname{van} \\
\text { tot }\end{array}$ & $\begin{array}{l}\text { AANT . STUKS } \\
\text { Ontv. }\end{array}$ & \multirow{2}{*}{ OORZAAK } & \multirow{2}{*}{$\begin{array}{l}\text { ParanF } \\
\text { Baze. } \\
\text { InB. }\end{array}$} \\
\hline & & & & & & & Door. & & \\
\hline
\end{tabular}

door den werkbaas en doorgegeven naar de Planning, welke op grond daarvan de statistiek-kaartjes bijwerkt en verplaatst naar de groep van de volgende bewerking. Voorts worden de loonstrooken op het calculatie-bureau gebruikt voor de bijwerking der kostprijskalarten, waarna zij naar het Joonbureau worden doorgezonden.

\section{Taststellen van het loon.}

Alhoewel de loonen volgens de reeds beschreven wijze op basis van het aantal stuks worden rastgesteld, dient het Loonbureau de op de loonstrooken vermelde tijden te contrôlecren, in verband waarmede zij per arbeider worden gesorteerd, waarna de tijden aan de laatste strook van de voorgande loonweek en onderling moeten aansluiten. Hiaten moeten opgehelderd worden. Zịj kunnen b.v. veroorzaakt zijn door het ontbreken van werkstukken, materialen of hulpmaterialen, door machinedefecten, enz. Indien de arbeider op deze factoren geen invloed kan uitoefenen, dan dient hị voor de verliestijden toch een behoorlijke vergoeding te ontvanger. Een juiste aanteekening van de tijden is noodzakelijk om overeenstemming met de contrôle-klokkaarten te verkrijgen en om de bewerkingstijiden zoo nauwkeurig mogelijk 
vast te stellen, zoowel ten behoeve van do productie-planning als voor het vaststellen van cen redelijk stukloon.

\section{Berekening van het loon.}

Aan de hand van de loonstrooken worden per arbeider loonberekeningsbladen bijgelıuden, welke bladen volgens model 4

Model 4.

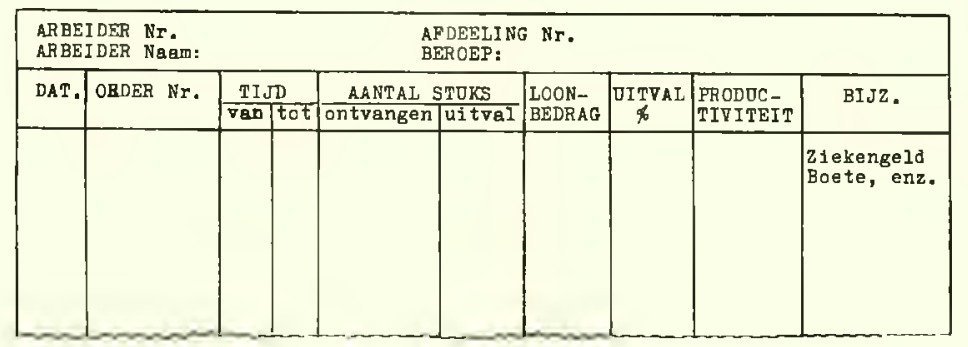

kunnen worden samengestcld. Ontvangt een arbeider voor zijn bewerkingen steeds het zelfde stukloon, dan kan het aantal doorgegeven stuks per week geteld en tegen het stukloon omgerekend worden. $\mathrm{B} i \mathrm{j}$ verschillend stukloon is gedurige aanteekening van het loonbedrag noodzakelijk. De berekeningen wegens zickengeld berusten op de desbetreffende van het aanstellingsbureau verkregen opgaven, welke op grond van de door de arbeiders ingediende ziekteformulieren an periodieke doktersverklaringen wekelijjks samengesteld worden.

Wekelijks worden de werktijden van de loonberckeningsbladen vergeleken met de tịjen van de contrôle-klokkaarten per arbeider en de in de afdeclingsrapporten eventueel voorkomende negatieve aanteckeningen betreffende oorzaken van afwezigheid, enz. Door het Calculatiebureau is reeds contrôlə uitgeoefend op het ontvangen en doorgegeven aantal stuks, zoodat deze gegevens door het Loonbureau kumnen worden aanvaard.

$\mathrm{Bij}$ de loonberekening moet in aanmerking genomen worden het aan het einde van elke loonweek in onderhanden zijnde werk, waarvan nog geen loonstrooken zijn ontvangen. Indien de betrokken werkuren het uit te betalen loon belangrijk beinvloeden, wordt aun den arbeider een voorschot gegeven op grond van de aan de onderhanden order gewerkte uren tegen uurloontarief. In verband hiermede verstrekken de betrokken werkbazen een opgave van de tijden, welke de arbeiders aan de order gewerkt hebben. De opgave vermeldt:

Model 6.
1. Arbeidersnummer.

2. Ordernummer.

3. Begin-tijd.

4. Gewerkte tijd.

Door de contrôle-klok is de begin-tijd op de desbetreffende loonstrook afgedrukt, zoodat de gewerkte tijd tot aan het einde ran de loonweek kan worden vastgesteld. Yoor het berekenen van deze tjjden worden ook wel de contrôle-klokkaarten gelruilit, hetgeen onjuist genoemd moet worden. Bedoelde klokkaarten moeten dienen als controlemiddel op de gegevens der loonberekening t.w. de tijden der ingeleverde loonstrooken en de onderhanden-werk-uren volgens de desbetreffende opgaven van de bazen. Deze opgaven dienen dus samengesteld te worden, hetzij in de aangegeven positicve vorm, hetzij in negatieve vorm. Welke van beide de voorkeur verdient, hangt af van de omstandigheden van elk bepaald geval. Bij de controle der werktijden moet vastgesteld worden, dat de begin-tijd van de loonstrook, betrekking hebbende op het onderhanden werk aan het begin der loonweek, aansluit bij de eind-tijd van de in de voorgaande loonweek laatst ingeleverde loonstrook.

\section{Uitbetraling van het loon.}

Aan de hand van de loonberekeningsbladen, de aanvullende opgaven der werkbazen, welke eveneens gegevens omtrent boete on dergelijkc inhoudingen bevatten, de loonkaarten voor de verrekening van vaste inhoudingen (ziekcnfonds-bijdragen), worden de loonkaarten per arbeider, de loonzakjes en de Loonlijst samengesteld, hetgeen in één arbeidsgang kan plaats vinden. Zoo mogelijk worden de loonkaarten gesortcerd per fabrieksafdecling, zoodat elke loonlijst de stukloonen van één bepaalde afdeeling bevat, warmede een beter overzicht der loonadministratie wordt verkregen. De loonlijsten (model 6) worden in triplo vervaardigd. Unicaten worden doorgegeven nal den kassier, welke de bedragen in de vereischte samenstelling fourneert en de desbetreffende zakjes, onder toezicht van een elke week wisselende employé, rult. Duplicaten ran de loonlijsten blijven op het Loonbur'cau ten behoeve van het oplossen van eventueele verschillen of onjuistheden. De triplicaten worden rechtstreeks doorgegeven aan en gedurende de reclametijd gedeponeerd bij het Klachtenbureau. opdat de arbeider's van de hen toegekende loonbedragen kennis kumnen nemen en de op de lijst voorkomende bedragen kunnen vergelijken met de bedragen van hun loonzakje. Laatstbedoeld exemplaar van de loon-

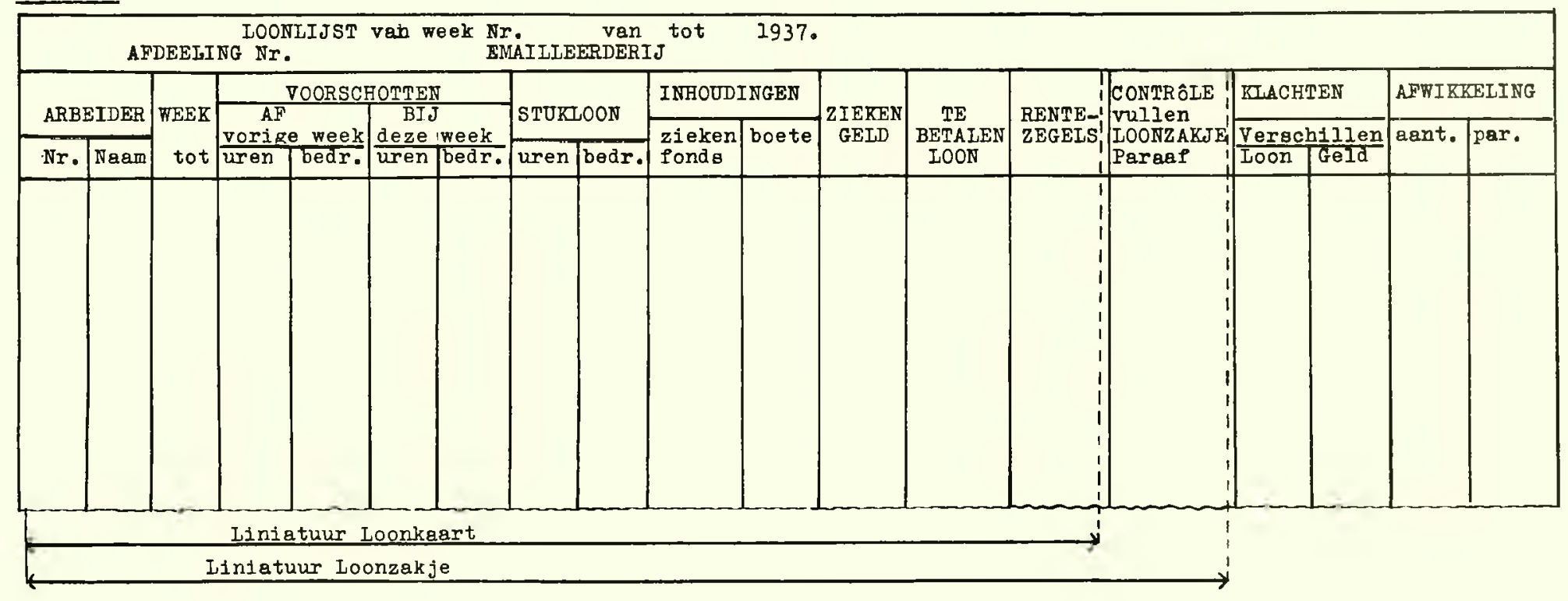


lijst komt niet in handen van den kassier, zoodat deze op de lijst geen wijzigingen kan aanbrengen. Reclames kunnen gedurende de reclametijd door de arbciders worden ingediend doos. middel van daartoe bestemde formulieren bij het Klachtenbureau.

\section{Interne looncontrôle.}

$\mathrm{Bij}$ de beschreven organisatic is nu rekening gehouden met de gewenschte functie-scheiding, t.w. :

1. Vaststelling ran het loon

2. Berekening van het loon

3. Uitbetaling van het loon

4. Behandeling der ingekomen klachten.

\section{Verband met kostprijsadministratie.}

De aansluiting aan de kostprijsadministratie wordt op de volgende wijze tot stand gebracht. De volgens het kasbock betaalde loonen worden ongesplitst gejournaliseerd, n.l.

\section{Betaalde loonen}

\section{AAN Kás}

Het rubricceren der loonen geschiedt op het Loonbureau volgens een Loon-splitsings-register, warin de verschillende loonstrooken verzameld worden. Deze veel tijd eischende werkzaamheden kumnen achterwege gelaten worden, indien men beschikt over de boven reeds aangegeven loonlijsten per afdeeling, alsmede afzonder]ijke lijsten voor de indirecte loonen. De totalen van de loonlijsten worden overgenomen in het Loon-splitsings-register, waaruit gejournaliseerd wordt :

Stukloonen emailleerderij

Stukloonen enz.

Voorschotten stukloonen

Sociale lasten

AAN te betalen loonen

AAN Zickenfondsbijdragen

AAN Boeten

AAN Voorschotten stukloomen

AAN te plakken rentezegels.

\section{Productiviteit der arbeiders.}

Ten behoeve van een juist stukloontarief dient de intensiteit en de productiviteit van de gepresteerde arbeid vastgesteld te worden. De benoodigde gegevens worden verschaft door de loonberekeningshladen, welke per arbeider het aantal bewerkte stuks, de uitval en de deshotreffende tijden aangeven. De productivitcit ran clke arbeider wordt uitgedrukt in het aantal bewerkte stuks per uur en het pereentage van de uitval. Zonder meer kan aan de mate van uitval geen groote waarde worden toegekend, daar de uitval door vorige bewerkingen of door werkfouten van de machines, waarop de arbeider geen invloed kan uitoefenen, kan zijn ontstaan. Wordt de productiviteit per arbeider per order bepaald, dan kan men het verloop resp. de mate van "Stetigkeit" gedurende de loonweek nagaan. Men zal trachten rast te stellen. of zckere schommelingen bij alle arbeiders optreden of alleen bị bepaalde werkzaamheden. Do intensiteit van de arbeid is te bepalen door de mate van overeenkomst resp. verschil tusschen. de gemiddelde productiviteit per loonweek en het hierboven bedoelde verloop der productiviteitscijfers gedurende de loonweek.

De verkregen eijfers betreffende gelijksoortige werkzaamheden worden statistisch vergeleken, op grond waarvan zoowel de stukloontarieven als de standaardtijden van de bewerkingen per serie worden vastgesteld.

\section{Indirecte loonen.}

De vaststelling der indirecte loonen geschiedt op grond der gegevens der contrôle-klokkaarten, welke vergeleken worden met de eventueele negaticre aanteckeningen volgens de fabrieksrapporten. Bij de loonberekening worden evencens loonlijsten per afdeeling samengesteld, waarvan de totalen in het Loonsplitsings-register wolden overgenonen. Bij het joumaliseeren wordt de rekening Indirecte productiekosten per afdeeling gedebiteerd in plaats ran de rekening stukloonen.

\section{Indivecte productie-kosten.}

De onder dezen hoofde vermelde kosten worden eveneens aan cen efficiency-contrôle onderworpen. De cffectieve (indirecte) liosten worden per afdecling, resp. per machine gerubriceerd en verzameld in daartoc bestemde Splitsings-registers. Voor het vergelijken van de op deze wijze vastgestclde totalen met de in de gereed gekomen producten doorberekende kosten, dient men cerst de optredende invloed van de bedrijfsbezetting te alimineeren, indien de werkelijke afwijkt van d.e normale bezetting. (1) grond waarvan de standaard-kostprijzen zijn berekend. De in de opslagrekening aan te brengen correctic wordt bepaald door het aantal bezettingseenheden, welke de afwijking aangeven, te vermenigvuldigen met het constante deel van de opslagkosten per cenheid. In geval van onderbezetting resp. overbezetting worden de opslagrekeningen gecrediteerd resp. gedebiteerd, wantegenover deze bedragen op de resultatenrekening als verlies resp. als winst zullen figureeren.

Het saldo der gecorrigeerde opslag-rekening dient nu vergeleken te worden met het effecticve kostenbedrag, waalma blijjkt welke graad ran bedrịjfszuinigheid door de verschillende functionarissen is bereilit. In dit verband kunnen als belangrijke kosten-categorië̈n genoend worden: de drijfkracht van de Ruw-fabricagc-afdeeling; het verbruik van het gemalen email in de emaillecrderij, welk verbluik niet per seric op directe wijze gemeten kan worden, doch door middel van een opslag, als deel van de indirecte productie-kosten der entaillecrder.ji, aan de verschillende sories toegerekend moet worden. Voor de beoordeeling van het verburuik dient men zooveel mogelijk het verband met de behandelde productie-orders vast te stellen.

Oppervlakkig beschouwd, zou men ten aanzien van de variabele kosten de daarvoor gestelde normen als basis voor vergelijking willen aanvalarden. Het is echter de vraag, of bedoelde liosten zuiver proportioned geacht mogen worden. Biijken deze kosten een disproportie te vertoonen, dan zal vastgesteld moeten worden, in hoeverre zij tot de unter- of überproportionale resp. de degressicve of prospressicve kosten-eategorieën gerekend moeten worden. Sommige door den calculator als variabel beschouwde kosten hebben gedeeltelijk een constant en anderdeels een variabel karakter. Bezien wị b.v. de verwarmingskosten van de oven, welke afhankelijk zịn van:

1. het op temperatum houden van den leegen oven ten einde een geheele afkoeling te voorkomen: verband met de tijd (en temperatuur).

2. het op temperatum brengen bij hot becrin van een proces: verband met het quantum product en de duur van het proces.

3. de tijd en het anntal der onderbrekingen: verband met de voortgang van het proces.

4. de werktemperatuur: verband met de smejtingswalmte van het mengsel.

Het zich hierbij voordoende auntal complicaties zal het onderzoek hoogst ingewikkeld maken, waaldoor de kosten liet nut ran deze werkzaamheden zouden kummen overtreffen.

Bij.j het onderzoek naar de oorzaken van de efficiency-verschillen der variabele liosten dient men derhalve terdege rekening te houden met de "Beschäftigungsgrad". Ten einde op 
ceonomische wijze tot een juiste beoordeeling to geraken, kan men gebruik maken van 'cn z.g. „flexible budget”, hetwelk wordt opgesteld roor versehillende graden van bedrijfsheretting. Het voorgaande geldt niet alleen voor de variabole doch eveneens roor de constante kostem. Men denke b.v. an de schonmolingen in de bedieningsloonen ten gevolge van overwerk; aam de, met het gebruik der machines rerband houdende, stijgende onderhoudskosten, de wijzigingen in de afschrijvingsquota en de rentebedragen. Ten flexible budget omvat derhalve een systeem ran stanclaarden, welke als basis voor de beooldecling bij velschillende verhoudingen in to bedrijfsbezetting kumnen dienen.

Alhoewel het flexible bulget derhalve als een vourtreffelijk hulpmiddel ter beoordeeling van de kosten kan functionneeren, dient gewezen te worden op en factor', welke doos theoretici meestal genegeerd of verwarloosd wordt en door welke het gebluik van het op ziels zo]f zoo muttige instrument tot gehec] onjuiste gevolgtrekkingron kan leiden. Iet de\%e factor bedoelen wij de invloed van de constellatie der bedrijfsbezetting op elk moment m.a.w. het verloop ran de bezetting. (Net de bovengenoemde ,Beschäftigmngsgrad" pleegt men altijd uit te drukken en totaliteit ran bezettingseenheden over een zekele periode, wolke methode feitelijk leidt tof cen onjuiste voorstelling. daar de bezetting nict voortcurend aan het uiteindelijk boreikte bezettingspercentage gelijk geweest ziju).

Een onderbezetting over een periode lian geëffectueerd worden door:

a. een gelijkhlijvende bezetting met verminderde of wisselende werktijd;

b. een gelijkhlijvende werktijd met verminderde of wissolende bezetting.

Het zal den lezer duidelijk ziju, dat b.v. de ovenkosten in het geval sub b hooger ziju dan in het geval sub a en wel tengevolge van het grooter aantal onderbs'kingen, het op temperatuur brengen of houden van den leegen oven en het onvolledig benutten van de inhoud van den oven. Niettemin is de totale productie over de betrokken periode in beide gevallen tot het zelfde cijfer gestegen. I[ieruit blijkt, dat de hudgeteijfers zonder meer niet als maatstaf kumnen dienen, zoodat men bij het samenstellen van deze eijfers met de gevolgen van de besproken bezsttingsversehillen terdege rekening zal moeten houden.

\section{VHRLOOP TAN IIET GEREED PROIULC'T}

Then amzien van de verkoop van het gereed product wijzen wij op de noodzakelijkheid ran de uniformiteit bij de behandeling van de op versehillende wijze binnenkomende orders. Te orders worken nitgegeven in viervoud, n.l.:

1. voor den afnemer;

2. voor den vertegenwoordiger;

3. wordt opgebolgen op datum ran rerzending;

4. wordt gesorteerd op artikel-soort.

De verzending blijkt nit de in triplo opgemaakte cxpeditielijisten en de namens de betrokken Stoomvartmaatschappijen geteekende cognossementen bij levering aan buitenlandsche afnemers. De facturen, in één bewerking samengesteld met de verzendingsstukten (meervoudige kettingformulieren, fan-, supcr- of interfold, gccarbonisecred of roorzien van énmalige (arbonbanen; toepassing ran arbonstel-apparaten), worden gebockt op cen Debitcurenkarert met gelijktijdig doorschrift op een blad (in duplo) ran een losbladig verkoopboek per rayon (I) uplicaten dienen voor de provisie-verrekening met de ver1egenwoordigers). Het bozwal, dat op deze wijze afgolein werk wordt verricht, wordt opgeheven door de langs andere weg to verkrijgen interne contrôle. I)agelijlss wordt cen raartoc bestemal telwerk vam de factureermachine vergeleken met het totail van de verkoopbladen; wekelijks worden de afleveringen rolgens de voorraad-administratie vergeleken met de totalen wegens verkocht produet volgens de betrokken verlivophladen. De wijze van bocking der v'reemule valuta-hedragen op de Deloiteurenkaraten is analoog an die ran de besproken Inkonpadministratic. Loerswinsten of -verliezen worden op ile\%olfde wịze berekend.

Ten kantore geseliedt de afboeking op de roorladalkarten door wekelijksche recapitulatie in ech datirtoe bestemde kolom. wialbij de ophrengst in de oorspronkelijke valuta (viachten, rechten, e.l. Initen beschouwing gelaten) wordt vermeld. De vecmde valuta wordt ongejekend tegen de rastgestelde gemiddelde mandkoersen. De versehillen tussehen de oplurengst on de rerkochte hoeveelheden, berekend tegen the stambardvoormadprijzen, bepalen de winst (of verlies) op de verlsoop. De veelonvattende werkzanmlicden tengerolge van het feit, dat ran clke factuul de verkoopprijs (in vrecmle valuta) omgerekend en het versehil tussehen het berekende bedrag on to kostprij.js vastgesteld moet worden, kimnen door de boven beschreven workwijze worden vermeden.

\section{Emballage.}

Bij goote omvang zal men de emballage afzonderlijk dienen te administrecren. Voor ke kisten wordt een vast bedrag hepaald, welk bedrag den afnemer in rekening wordt gebracht. Bij terugzending wordt de client op basis van bedoeld bedrag arecreditecred.

Wordt verpakking niet afzonderlijk in rekening gebracht, dan dient in de kostprijs van het product een opslag voor dekking van de cmballage-kosten herekend te zịn. De op die wijzo doorberekende kosten worden dan gesteld tegenover de werkelijke kosten van de emballage-afilecling, inel. het kisten-verbruik.

\section{Transport.}

De kosten van transport in het limmenland knmen i.e. voor cigen rekening. Ten einde ecu juiste eontrole op deze Tiosten te kumnen nitoefenen, wordt een cxemplaar van de expediticlijsten gehruikt voor aanteckening van als op de betrokken zendingen vallende transportkosten. 1)eze anteckening gesehiedt rollectief per lijst of individucel per zending. Het fotaal van de volgens de lijsten verantworde vinchten moct orerecmstenmen met de desbetreffende betalingen volgens het lashock. Worden de rachtkosten (abusicvelijli) tweemaal hetalkl. dan leidt zullis tot een versehil tussehen expeditie-lijsten en Vrachtenrekening. Te deshet reffende hotalingshoscheiden worken alan de hand ram de expeditic-lijsten onummeld en in nummervolgorde opgchorgen.

Ten slotte kumnen de expelitio-lijsten inzieht geven in de samenstelling van het transport en de daaluit voortvociende kosten. Op basis van de verhouding tussehen vervoert cuantum en transnortkosten kan do officieney emigermate beordecld worden. TTier zal de intütie den beoordeelatr bij het maken van ziju gevolgtrokkingen to hulp moctem komen, laar in de meeste gevallen gen bruikhare normen kumnen woyden bepaald.

In het geval het bedrijf de beschilking ored eigen transportmiddelen heoft, doen zich ton amzien van hot vaststellon der transmortkosten, het vergelijken van deze kosten met de kosten van 1 ramsport door derelen, en het eventueel doorberekenen van de transpottiosten aan de afnemers, versehillende problemen

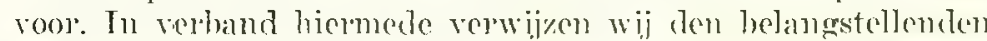
lezer natr een van onzen hand in het malandblad Arhministm- 
tieve Arbeid ${ }^{1}$ ) verschenen artikel betreffende het vervoerbedrijf, warrin o.a. behandeld worden de opbouw, de verantwoording en de bedrijfseconomische contröle der autokosten, alsmede cen artikel ${ }^{2}$ ) betreffende administratieve problemen van het transportbedrijf, warin de opbouw van transporttarieven door ons ter sprake werd gebracht.

Met de gegeven behandeling, welke geen aanspraak wil maken op volledigheid, daar details van elk bedrijf „an und für sich" afhankelijk zijn, hebben wij getracht voor enkele bij het vraagstuk naar voren komende problemen een practische oplossing te geven. Aher ......., Die Welt ist meine Vorstellung", (Schopenhauer).

\section{VAN DER BURG.}

Accountant N. T. v. A.

1) Administratieve Arbeid 1936, pag. 1, 43, 55 e.v.

-) Administratieve Arbeid 1937, pag. 198 e.v.

\section{UIT HET BUITENLAND \\ Red.: F. HAARBOSCH, CH. HAGEMAN, Drs A. TH. DE LANGE en Drs W. P. DEN TURK \\ (Bijdragen en mededeelingen zende men aan den Secretaris der Redactie)}

\section{De "Spruchstelle"}

Enkele maanden terug vermeldden wij in een artikel over het Duitsehe Naamlooze Vennootschapsrecht dat in Duitsehland een spruchstelle in het leven is geroepen om bindende uitsprak te doen in kwesties tussehen accountant en directie, bij de vervlichte controle der jaarrekening.

Der Wirtschaftstreuhânder van 15-11-'37 bevat een artikel ran Dr. Adler uit Ber]ju, dat meer gegevens omtrent deze nieuwe rechterlijke instantie verstrekt.

De competentie der Spruchstellen gaat niet verder dan kwesties over nitlegging der voorschriften t.a.v. halans en jaarver'slag, voorzoover dit laatste aan de goedkeuring van den accountant is onderworpen.

Deze kwesties kumnen betreffen o.m. rubricceringsviagen, waardecringsproblemen en de vorming van stille reserves.

De beslissingen van de Spruchstelle zijn bindend voor ieder. die ermede to maken heeft.

Wcliswalr kan de onderneming in overleg met den accounfant ervan afwịken, maar de vaststclling van balans en jaalverslag kan dan achteraf worden nietig verklaard.

Hamneel de Spruchstelle in een kwestic tusschen accountant en onderneming den accountant in het ongelijk stelt, is deze practisch wol tot teekenen der jaarrekening verplicht, zooals ze op aanwijzing van de spuruchstelle is opgemaakt. Weigert hij, dan staat aan de ondememing de mogelijkheid open hem een accoordverklaring in rechten af te dwingen. Verder stelt hij zich bloot aan tuchtrechterlijke actie door de daartoc bevoegde beroepsinstanties.

Andere rechterlijke colleges zijn rolledig aan de uitspraken del onderhavige instantie gebonden. Ook de fiscus heeft posten, welke door de Spruchstelle zijn goedgekeurd, in dien vorm en tot dic bedragen te anvaarden. Gesteld natuurlijj dat ook de hoogte der bodragen voor de Spruchstelle in het geding is geweest.

Naar Dr. Adler vermoedt zal de instelling der Spruehstellen een sterke preventieve werking hebben. Wanneer het inderdaad tot een procedure komt, zal het meestal de directie zijn, die een zaak aanhangig maakt. Immers, de accountant zal, wanneer hij zijn handteekening heeft geweigerd, meestentijds geen aanleiding tot eenige actie meer hebben.

Buiten den accountant en de directie van de onderneming over welker jarrekening let gaat, kan niemand zich tot de Spruchstelle wenden. De Directic kan het bovendien alleen doen wanneer de accountant weigert het „Bestatigungsvermerk" af to geven of het slechts met een voorbehoud wil verstrekken. Opmerkingen, door den accountant in zijn toelichtend rapport gemaakt, kumnen nooit aanleiding tot een procedure geven.

De Spruchstelle heeft bevoegdheden om alles te doen dat tot opheldering der aan haar oordeel onderworpen kwestie kan leiden. Neer speciaal mag zij deskundigen hooren. Geen beslissing kall rechtsgeldig worden genomen, wanneer partijen niet zijn gehoord. De beslissing moet behoorlijk gemotiveerd aan partijen, d.i. aan accountant en directie, worden ter hand gesteld.

Het is uiteraard gewenscht dat de procedures voor de Spruchstelle snel verloopen. Dr. Adler gaat zelfs zoo ver dat hịj een interpretatic der wettelijke bepalingen zou wenschen, volgens wolke men, hangende kwesties welke geen betrekking hebben op het roor uitdeeling beschikbare winstbedrag, tot een voorloopige vaststelling der jaarrekening zou kumnen geraken. B.v. wanneer het slechts de benoeming der posten betreft. $\mathrm{Na}$ de uitsprak der Spruchstelle zou hị dan een definitieve vaststelling willen laten volgen. Ter bevordering van bekwamen spoed is ook samenwerking tusschen de partijen gewenscht. Accountant en directie moeten trachten van te voren reeds tot een omschrijving der kwestie to komen, waarover ze het niet eens zijn. Dat spaart aan de Spruchstelle werk en dus tijd. Betoog en tegenbetoog moeten gelijktijdıg worden ingediend. Wanneer men mondelinge toclichting wenscht te geven, stelle men reeds bij de indiening van het eerste vertoogschrift de Spruchstelle daarvan in kennis. Wenscht men memoranda in te dienen, opgesteld door deskundigen, dan doe men dat zoo spoedig mogelijk, zonder een officiecle uitnoodiging daartoe tijdens de behandeling der zaak af te wachten.

Toen wij in onze jonge dagen met een aardig meisje, nader genaamd zoete lieve Gerritje, naar den Boseh toe wilden gaan, werden wij reeds voor de vraag gesteld wie de kosten van zulk een expeditic zou moeten betalen.

Jeze vrag is ook gesteld t.a.r. de procedures der Spruchstellen. Principicel moct de gecontroleerde onderneming hier de rol vervullen vall, "le jongens die ons halen". Slechts wanneer blijkt dat het den accountant ontbroken heeft aan den noodigen crnst bij het uitlokken der procedure, kunnen de kosten to rijnen laste worden gebracht.

Iet is ons niet mogelijk aan te nemen dat er ooit ergens in de wercld accountants zouden worden aangetroffen, die niet van den noodigen levensernst zijn voorzien. De accountant betaalt dus nooit.

Sterker nog, wanneer hịj zelfs als verliezende partịj, niet op een gebrek aan ernst is betrapt, kan hij roor den tijd en don arbeid, door hem aan de procedure besteed, een declaratio indienen bij de betrokken onderneming.

„Für den durch das Verfahren vor der Spruchstelle verursachten Keitaufwand (schriftsätzliche Aüszerung, mündliche Verhandlung usw.) kann der Wirtschaftsprüfer nach $\S 3$ der Gebührenordnung für Pflichtprüfungen liquidieren, da eine lnanspruchnahme seiner Arbeitskraft im Rahmen der Pflichtprüfung vorliegt'”.

O ideale zeden! Maak kwesties net uw cliënt, laat U door uw cliënt dagraarden, en declareer hem den arbeid, aan uw verdediging verbonden. I Jaat geen accountant ter wereld ooit 